\title{
系統連系太陽光発電システムにおける
}

\section{インバータ損失を考慮したMPPT 制御法}

\begin{tabular}{|c|c|c|c|c|}
\hline 生 & 成 & 毛 & 貴 & (工学院大学) \\
\hline & 青 & 木 & 崇 & (工年 \\
\hline & & 㽖 & 一 & (I学 \\
\hline & & & 芳 & （工学院大学 \\
\hline
\end{tabular}

A Maximum Power Tracking Control Method Considering Loss of Inverters for Utility Interactive Photovoltaic Generation System

Takashi Naruke, Student Member, Takashi Aoki, Student Member, Ichiro Takano, Member, Yoshio Sawada, Member (Kogakuin University)

キーワード：太陽光発電、系統連系、インバー夕、最大出力追従制御（MPPT 制卸）

1. はじめに

クリーンで無尽蔵である太陽光発電システムにおいて、 奻率向上を図るため、インバータ等の雨力変換器により太 陽電池（以下 PVと略す。）を最大出力で動作させる制御 (以下 MPPT制御と略す。) 亦必要とされる。

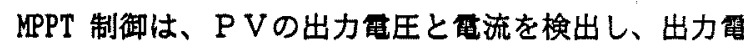
力を演算して行う方法が一般的であるが(1)、インバータ の回路損失を考虑した MPPT 制御を適用した例は少ない。

そこで本稿では、従来の方法の一つでもある山登り法に 着目し、 $\mathrm{AC}$ 側出力検出によりインパー夕損失を考虑し、 さらに制御回路の简略化について検封したので、その制御 方法及び実験結果について報告する。

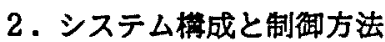

图 1 に、太陽電池の電压・西流特性、太陽電池出力電力 及び系統返這電力特性の一例を示す。このように系統側で は、変撸器の回路損失により最大出力点がずれた状態とな る。そこで AC 侧出力を検出する事により回路損失が考虑 てきる。系統運系の場合、 $\mathrm{AC}$ 側出力電圧がほぼ一定のた め力率 1.0 て運転すれば、AC 倒出力神流を検出する事に よりその電力の変動を検出する事が可能となる。これによ り、単に電压、電流の計測たけで济み制御回路は简単化さ れる。

次に、インバータの直流電圧指令值の增減方向を容易に 決定する方法を提案する。

$\mathrm{PV}$ 側電压、AC 側電流の值をサンブリングし、それぞれ 今回 $\left(V_{N} 、 I_{N}\right)$ 、前回 $\left(V_{B} 、 I_{B}\right)$ とするとその変化分 は次式になる。

$$
\Delta \mathrm{V}=\mathrm{V}_{\mathrm{N}}-\mathrm{V}_{\mathrm{B}}, \Delta \mathrm{I}=\mathrm{I}_{\mathrm{N}}-\mathrm{I}_{\mathrm{B}}
$$

これから $\Delta \mathrm{V} * \Delta \mathrm{I}$ の変化分における積の符号より直流電
圧指令值の增減が決定でき、その指令值は次式になる。

$$
\mathrm{V}_{\mathrm{N}+1}=\mathrm{V}_{\mathrm{N}}+\mathrm{k}(\Delta \mathrm{V} * \Delta \mathrm{I}) \quad \mathrm{k} \text { : 比例定数 } \cdots \text { (2) }
$$

また、その指令值の增隇方向の関係を表 1 に示す。 以上の制御方法を踏まえ、実際に試作し、単相電压形人 ンパータを用いたシステム粠成四を四 2 に示す。

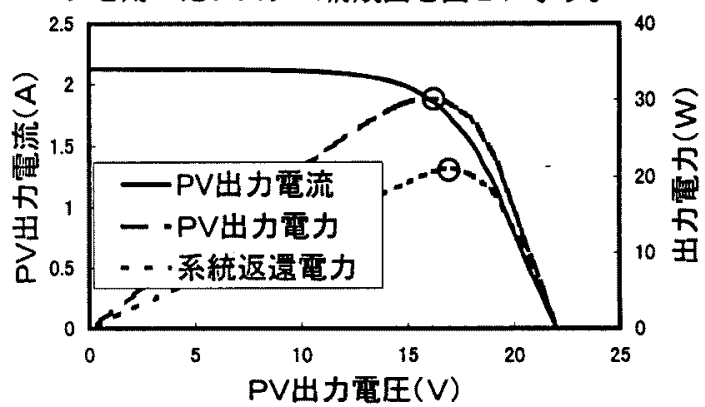

図 1：PV出力及び電力特性

Fig.1. Output characteristics of PV.

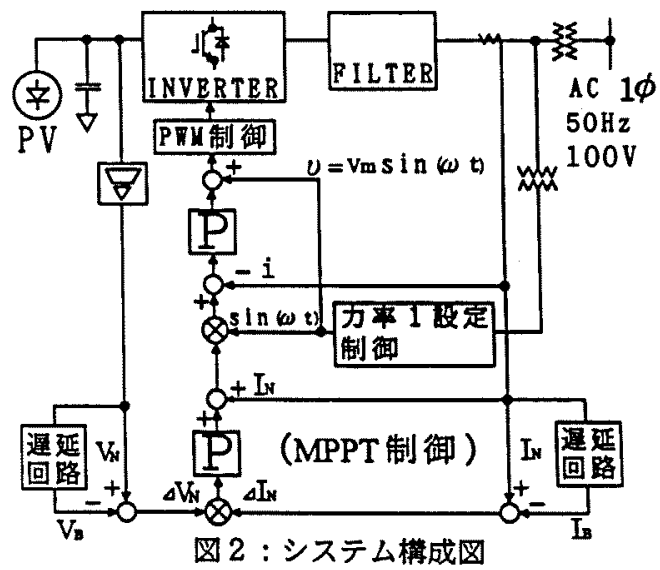

Fig.2. System configuration. 
表 1 : 直流電圧指令値の增減方向

Table 1. A performance of VI tracking.

\begin{tabular}{|c|c|c|c|}
\hline $\begin{array}{c}\text { PV 電圧差 } \\
(\Delta \mathrm{V})\end{array}$ & $\begin{array}{c}\mathrm{AC} \text { 電流差 } \\
(\Delta \mathrm{I})\end{array}$ & $\begin{array}{c}\Delta V * \Delta I \\
\text { の符号 }\end{array}$ & 増減方向 \\
\hline$\Delta V>0$ & $\Delta I>0$ & + & 增 \\
\hline$\Delta V>0$ & $\Delta I<0$ & - & 隇 \\
\hline$\Delta \mathrm{V}<0$ & $\Delta I>0$ & - & 減 \\
\hline$\Delta \mathrm{V}<0$ & $\Delta I<0$ & 7 & 增 \\
\hline
\end{tabular}

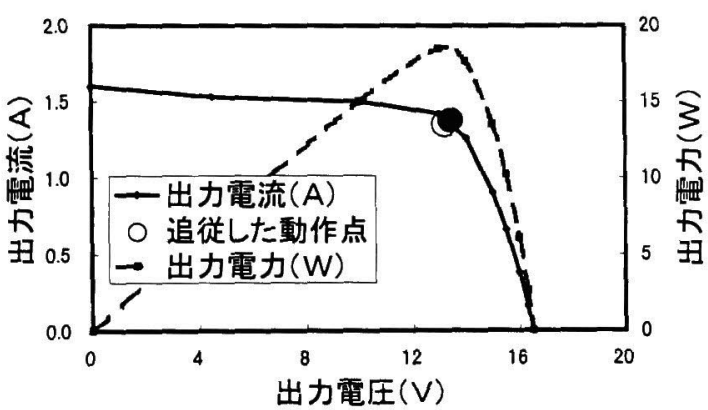

図 $3:$ MPPT 制御時の太陽雷池の動作点

Fig. 3. PV operational point by MPPT control.

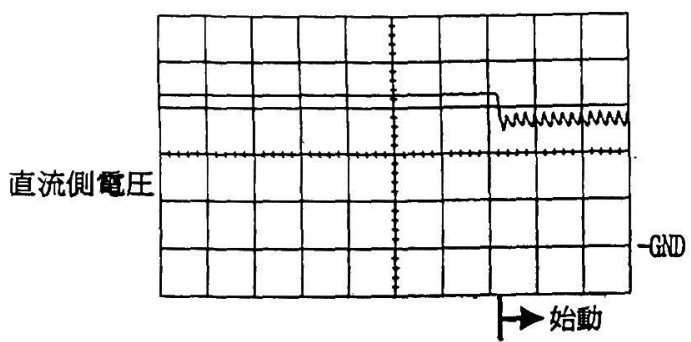

( Time : 50ms/DIV、Volt : $5 \mathrm{~V} / \mathrm{DIV}$ )

図 4 : 直流入力電圧の実測波形

Fig.4. Expermemtal waveforms of DC voltage.

\section{3. 実験結果}

困 3 に、MPPT 制御による太陽電池の動作点を示す。最 大出力点付近で動作していることがわかる。

図 4、5にインバータが停止状態から始動し、MPPT 制 御により最大出力点付近で動作したときの各入出力波形を 示す。直流電圧には、 $\mathrm{AC}$ 出力電流の整流リップルに起因 する2 倍周波のリップルが生じているが、AC 出力電流は ほぼ一定であり、MPPT 制御による振動が生じない結果と なっている。また、インバータは力率 1.0 運転している。 系統連系によりインバー夕出力電圧がほぼ一定であり、イ ンバータ出力電力は、出力電流とほぼ比例するため、図 5 より安定した最大出力に近い電力を系統側に供給可能であ ることがわかる。

4.まとめ

本論文では、 $\mathrm{AC}$ 側出力を検出によるインバー夕損失を 考虑した MPPT 制御を提案した。さらに実験によりインバ 一夕の直流電圧指令值の增堿方向が容易に決定できる事を 実証することができた。（平成 10 年 3 月 23 日受付）

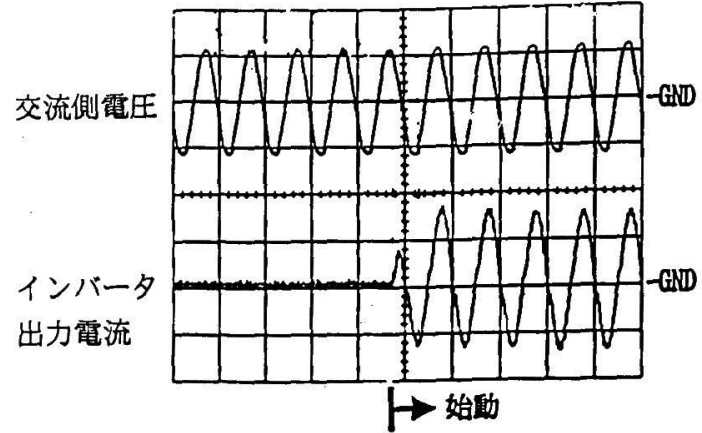

(Time : $5 \mathrm{~ms} / \mathrm{DIV} 、$ Volt : 100V/DIV、Amp : 0.15A/DIV) 図 $5:$ インバータ出力の実測波形

Fig. 5. Expermemtal waveforms of inverter output.

\section{文 献}

（1）電気学会技術報告 第 551 号 新エネルギー用半章 体電力変換技術の現状と動向 P 8 20 1995 年 6 月

（2）成毛、他：「系統連系太陽光発電システムにおける $\mathrm{AC}$ 側出力検出による最大出力追従法」平 8 年電気学 会産業応用部門全大 $\mathrm{T}-40$

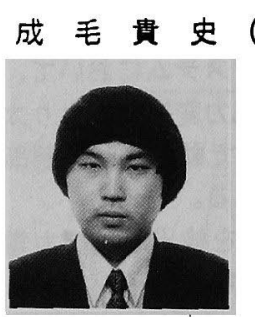

(学生員) 1973 年 3 月 14 日生。1998 年 3 月工学院大学大学院工学研究科修士 程修了。主として太陽光発電システム の関する研究に従事。1998 年 4 月(株) 富士通ゼネラル入社予定。

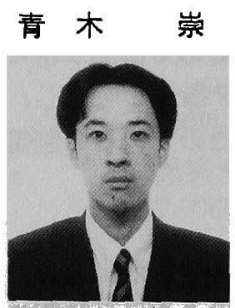

(学生員) 1974 年 9 月 11 日生。1997 年 3 月工学院大学工学部門気工学科卒業。 現在、同大学大学院工学研究科修士課 程在学中。主として太陽光発電システ 么に関する研究に従事。

鷹 野 - 朗 (正員) 1959 年9月11日生。1989 年

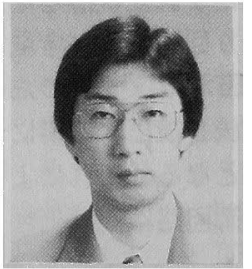
工学院大学大学院工学研究科博士課程 修了(電気工学尃攻)。現在、工学院大 学電気工学科䎸教授。工学博士。主と して、イオンビームを用いた薄膜形成 の研究に従事。忠用物理学会、表面技 術協会、電子情報通信学会会員。

澤田芳夫（正只）1938年1月22 日生。1960年

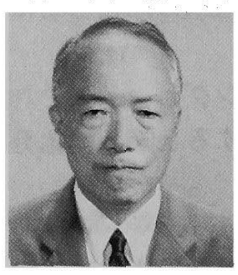
3 月東京大学電気工学科卒業。同年 4 月東京芝浦電気（株）(現（株）東芝） 入社。同社重電技術研究所にて、パワ 一エレクトロニクス装䈯、回転機、超 伝迸なとの研究開発に従事。1995 年 4 月より工学院大学菓気工学科教授。工 学博士。 